\title{
Geographies of knowing, geographies of ignorance: jumping scale in Southeast Asia
}

\author{
Willem van Schendel 9 \\ Asia Studies in Amsterdam, University of Amsterdam, Oudezijds Achterburgwal 237, \\ 1012 DL Amsterdam, The Netherlands; e-mail: vanschendel@pscw.uva.nl \\ Received 6 February 2002; in revised form 27 March 2002
}

\begin{abstract}
Area studies' use a geographical metaphor to visualise and naturalise particular social spaces as well as a particular scale of analysis. They produce specific geographies of knowing but also create geographies of ignorance. Taking Southeast Asia as an example, in this paper I explore how areas are imagined and how area knowledge is structured to construct area 'heartlands' as well as area 'borderlands'. This is illustrated by considering a large region of Asia (here named Zomia) that did not make it as a world area in the area dispensation after World War 2 because it lacked strong centres of state formation, was politically ambiguous, and did not command sufficient scholarly clout. As Zomia was quartered and rendered peripheral by the emergence of strong communities of area specialists of East, Southeast, South, and Central Asia, the production of knowledge about it slowed down. I suggest that we need to examine more closely the academic politics of scale that create and sustain area studies, at a time when the spatialisation of social theory enters a new, uncharted terrain. The heuristic impulse behind imagining areas, and the high-quality, contextualised knowledge that area studies produce, may be harnessed to imagine other spatial configurations, such as 'crosscutting' areas, the worldwide honeycomb of borderlands, or the process geographies of transnational flows. Scholars of all conventional areas can be involved in this project to 'jump scale' and to develop new concepts of regional space.
\end{abstract}

Sit down in any food stall and listen to the people around you. Imagine you are a language expert. Enjoy the flow of Mon-Khmer from the tables around you. Listen to the children in the street shouting in Tibeto-Burman and to the song in IndoEuropean floating from the radio. Observe newspapers in five different scripts lying on the counter. Order your bamboo-shoot lunch in any of a handful of languages and guess where you are. Welcome to ... Southeast Asia?

Well, yes and no. We are in Shillong, a town in northeastern India. Is this Southeast Asia? And if so, why? Does it matter? In this paper, I look at the 'geographies of knowing' that have come about as a result of the academic regionalisation of the world in the second half of the 20th century. My special interest is in looking at the margins of these geographies, or the fringes of the intellectual frameworks known as 'area studies'. The region around Shillong could be described as the northwestern borderland of Southeast Asia, or as the northeastern borderland of South Asia. I examine the issue of 'area borderlands' from the perspective of Southeast Asia. Thus Shillong may stand for towns as dispersed as Antananarivo, Trincomalee, Merauke, and Kunming.

\section{The scramble for the area}

The academic division of the world after World War 2 was neither a military campaign nor an administrative campaign but it showed a certain resemblance to the scramble for Africa two generations earlier. First, like its precursor, its impetus was political and external to the areas concerned: it emanated from North America and Europe, which were not really considered to be 'areas' themselves. Second, it resulted in lines being drawn on the world map that were just as bold as the imperial boundaries conceived at

- Correspondence address: International Institute of Social History, Cruquiusweg 31, 1019 AT Amsterdam, The Netherlands. 
the Berlin Conference; in fact, they often followed imperial boundaries. And third, it created conceptual empires that were thought of as somehow essentially homogeneous and self-contained, and it deemphasised preexisting social realities cutting across the boundaries of the newly conceived 'areas', with the exception of those with (neo)colonial powers.

The scramble for the area led to an institutional anchoring of academic communities worldwide, which trained separately, became engaged in area-specific discourses and debates, formed well-established reference circles, and developed similar mechanisms and rituals for patrolling their intellectual borders. The emergence of what came to be known in North America as 'area studies' was a source of strength but could also lead to obscurantism and even in their least hidebound forms area studies hampered information flows between the new intellectual arenas. It is hardly surprising that today a Latin Americanist listening in on a conference of Africanists, or a scholar of the Middle East among Southeast Asianists, feels rather like an Anglophone African at a meeting of Francophone co-continentals. But even those who specialise in the study of contiguous world areas have trouble following what goes on next door. For example, at Asian Studies conferences it is easy to observe how strongly specialists of different areas within Asia interact within their own regional subgroups and how little they interact across them. Even during coffee breaks, regional subgroups on, for example, South Asia or Southeast Asia can be seen to persist, varying from sharply bounded jatis to more vaguely demarcated mandalas. ${ }^{(1)}$

Meanwhile, the scramble for the area is not over, it is continuing. As the world has moved beyond the political realities of the mid-19th century that gave rise to area studies, academics have attempted to adapt their areas accordingly. This can be seen clearly in the emergence of a new academic area, 'Central Asia', during the 1990s. (2) Areas have also changed because each became a nexus of changing relations between specialists in the area and their 'Northern' colleagues; these relations varied from antagonistic to collaborative and evolved in area-specific patterns. Over several generations old now, these webs of relationships have developed into 'area lineages', imagined area communities whose disputes and preoccupations draw them ever closer together and who have created their own distinct systems of rewards, sanctions, and taboos. In formerly colonised societies, members of the rapidly developing intelligentsias with international ambitions had little choice but to adapt to the area mould. Moreover, the closing years of the 20th century have seen the project of area studies itself coming under fire, particularly in the United States, which had gone furthest in institutionalising it. A heightened awareness of global economic and financial connections, international migration, and deterritorialised and diasporic identities resulted in the charge that area studies fetishised the local-and this impelled area studies to rework their claim that knowledge production without 'contextualisation' was, at best, woefully incomplete. And finally, it is gradually dawning upon those who have specialist knowledge of Europe, North America, or Australia that they are as much

(1) Among scholars of South Asia the term 'jati' is used to denote endogamous groups with clear social boundaries ('subcastes'); Southeast Asianists use the term 'mandala' to refer to precolonial political entities whose geographical extent and borders were only vaguely defined.

(2) This area is still an unsettled unit, as indicated by the terminological confusion surrounding it. Many writings on Central Asia deal exclusively with the former Soviet part, now divided between five independent states east of the Caspian Sea. Some, however, also include the ex-Soviet states in the Caucasus. Lewis and Wigen (1997, pages 176-181) propose a much larger area, covering the states east of the Caspian Sea, Sinkiang, Mongolia, and Tibet. Others demur, such as Soucek (2000), who argues that only the ex-Soviet part is 'Central Asia', and that the region which Lewis and Wigen propose should be named 'Inner Asia', or Christian (1994), who proposes the term 'Inner Eurasia'. In the Journal of Asian Studies books are reviewed under the heading 'China and Inner Asia'. 
engaged in area studies as their colleagues spending a lifetime analysing Africa or Latin America.

\section{What is an area?}

There are three principal ways of understanding an academic area: as a place, as a site of knowledge production, and as a career machine. Let me illustrate this by taking the example of Southeast Asia.

Many have described Southeast Asia as a physical space, a geographical region, an area that can be pointed out on the globe. ${ }^{(3)}$ But Southeast Asianists have been remarkably diffident about their region, which does not have the distinctive continental shape of Africa or Latin America and is a collection of discontinuous territories united by large bodies of water. ${ }^{(4)}$ As Southeast Asia lacks the geographical obviousness of other areas, Southeast Asianists have emphasised the human ties that make the region a unit. In the construction of this region as a social space, the physical intent was infused with a more liberal dose of social intent than elsewhere (Smith, 1990).

But even when it comes to the people inhabiting these territories, they are often described in terms of what they are not. Recently, Charles Keyes said that Southeast Asia is a region comprising the "people living east of India and south of China and north of Australia" (in Weighing the Balance 2000, page 8). Others have tried to emphasise the unity of the region's peoples by suggesting that they are characterised by "shared ideas, related lifeways, and long-standing cultural ties" (Lewis and Wigen, 1997, page 158). Usually it remains vague which cultural ties actually are deemed crucial in defining Southeast Asia, although civilisations, languages, and religions are proffered as alternatives. ${ }^{(5)}$ What these definitions share is a concern to present Southeast Asia as a well-bounded geographical place with a certain internal consistency and a regional je ne sais quoi, an essence that even area specialists find hard to put into words. ${ }^{(6)}$ As a result, the geographical boundaries of the region remain highly problematic: civilisations, languages, and religions have never coincided with each other, nor with the contemporary political boundaries that most Southeast Asianists accept as the spatial limits to their quest for knowledge.

Another way of thinking about an area is to consider it as a symbolic space, a site of theoretical-knowledge production rather than as a mere object of specialist knowledge (Morris, in Weighing the Balance 2000, page 11). Neferti Tadiar suggests that:

(3) Agnew (1999, page 92) has described this approach as that of realists, for whom "the 'region' typically conjures up the idea of an homogeneous block of space that has a persisting distinctiveness due to its physical and cultural characteristics. The claim is that it exists 'out there' in the world." They find themselves in an 'unfortunate opposition' with constructionists, "who regard all regions as mere inventions of the observer whose definitions say more about the political-social position of that observer than the phenomena the regions purport to classify."

(4) Southeast Asia specialists have been discussing the nature and identity of their area, as well as their own achievements and shortcomings, to an extent completely unknown to their colleagues specialising in, for example, South Asia (see Emmerson, 1984; Hirschman et al, 1992; Solheim, 1985; Weighing the Balance 2000).

(5) But culturalist criteria make geographic definitions highly problematic. As Hill and Hitchcock (1996, page 12) argue, "in ethnographic terms parts of Northeast India, Southern China and Taiwan can be said to belong to Southeast Asia whereas Irian Jaya has much in common with the Melanesian world."

(6) This is - rather enigmatically for the uninitiated-how it is put in the preface to The Cambridge History of Southeast Asia: "Southeast Asia has long been seen as a whole, though other terms have been used for it. The title Southeast Asia, becoming current during World War II, has been accepted as recognizing the unity of the region, while not prejudging the nature of that unity. Yet scholarly research and writing have shown that it is no mere geographical expression" (Tarling, 1999, volume 1, page xi). 
“the 'area' of Southeast Asia can be understood more as a theoretical problematique than as an object of inquiry - similar to the way we understand 'cultural studies' as an 'area' offering new sets of questions and methodologies" (in Weighing the Balance 2000, page 18).

This approach invites a sociology of knowledge of Southeast Asia. How has the field of Southeast Asia been constituted by the predilections, traumas, and theoretical fashions of North American, European, Australian, Japanese, and Southeast Asian academic institutions? Is it possible to define the 'theoretical problematique' in any unequivocal way? What is the canon that is being taught to new entrants in the field? What are the questions and methodologies that Southeast Asia has to offer to other fields? And, in the wider context of area studies, some crucial issues are how a 'regional' system of knowledge, with its emphasis on the specificity of spatial configuration, relates to other regional systems, what the mediations are between these and an overarching social theory, and what contributions area studies can make to an ongoing spatialisation of that theory. ${ }^{(7)}$

Finally, Southeast Asia can be thought of as an institutional space, as the name of a group of transnational scholarly lineages, circles of referencing, structures of authority and patronage. In this perspective, 'Southeast Asia' is both a global mutual-support society and a network for protecting, promoting, and validating particular kinds of expertise. This transnational community is dominated by established scholars who act as gatekeepers to a controlled 'area' labour market, to which selected young trainees are given access. At stake is the protection and, if possible, expansion of the field within universities, research institutes, and centres of policymaking. Scholars of Southeast Asia (or any other 'area') act as lobbyists for their field. Today, one of the worries that plagues Southeast Asianists is the fact that a generation of towering figures in the field has reached retirement age. It is feared that this will weaken 'Southeast Asia' both as a scholarly project and as a career machine.

\section{The structure of area studies}

Regional studies use a geographical metaphor to legitimate the production of specific types of knowledge. This knowledge is structured geographically as well as according to academic disciplines. The geographical metaphor demands that one 'area' ends where the next one begins, but in reality area studies resemble the mandalas of old. Kingdoms in some parts of what is now called Southeast Asia were powerful and well defined at the centre but vague and contested at the edges. They would expand and contract in concertina-like fashion depending on their relationship with surrounding political entities, and there were often areas in between whose political status was undecided. Area studies are like that. They lack clear boundaries and may lay claim to new territories if it suits them. A good example is Afghanistan, which is variously included in, or omitted from, the Middle East, Central Asia, and South Asia.

Some area studies have a strong central court. South Asian studies are a case in point. Here most scholars work on India, perhaps even North India. By contrast, Southeast Asian studies appear to form a more multicentred mandala based on an alliance of three major provincial factions: the Indonesianists, the Thai experts, and the Vietnamologists (Weighing the Balance 2000, pages 17-20). The concerns of these groups dominate the field. They tolerate weaker factions at the peripheries, for example, those generating scholarly knowledge about lesser satrapies known as the Philippines, Laos, Malaysia, or Burma (Myanmar). And then there are the marches, the borderlands that separate the region from other world regions. In the case of Southeast Asia these are the 
liminal places referred to above: Northeast India, Yunnan, Sri Lanka, Madagascar, New Guinea, and so on. Those who produce specialist knowledge about these places may occasionally be invited to court, but they will never be a part of the power elite. In true mandala fashion, these marches are sometimes claimed as part of some regional problematique, but always from the vantage point of the court. The borderlands are rarely worth a real fight - they are more often forgotten than disputed between neighbouring areas.

Similarly, regional studies are structured by discipline, some offering higher status (and better career prospects) than others. A recent overview suggests that anthropology and history dominate in Southeast Asian studies, although another group of specialists might perhaps have come up with more policy-oriented disciplines (Weighing the Balance 2000). But clearly, some disciplines have low status. In terms of career planning, a student would be wiser to train as an anthropologist than as a geographer, and she or he would be wise to choose Java rather than Cambodia. This is not, of course, because the geographical study of Cambodia is inherently less important than the anthropological study of Java - in fact, one might reason that an individual scholar's impact on knowledge production can be greater in a relatively undeveloped field - but because of the reward system operating among those who define area relevance.

\section{An area of no concern}

The current refashioning of area studies as a scholarly project may sadden many disciples but may come as a relief to others. They welcome a reconsideration of the contexts, boundaries, and types of knowledge associated with the scramble for the area. And it is not only the 'globalists' who have been chomping at the bit. ${ }^{(8)}$ Others have long felt that, in a bid for academic recognition, proponents of area studies have overstated their case. Under the banner of area studies, particular academic fiefdoms have been allowed to flourish at the expense of others. Even those who feel that the idea of area-based academic activity is sound may rebel against the status quo. For example, although many Southeast Asianists think of their area as a young and fragile one still waiting to come into its own, they have been put on the defensive by newcomers who describe Southeast Asia as a 'traditional area' and who propose new regional contexts, for example, the 'Indian Ocean', or 'Asia-Pacific'. (9)

The construction of spaces in which human activity is thought to take place is always contested, and so is the production of knowledge about these social spaces, their "geographies of knowing" (Gregory, 1994). Because spatial metaphors are so important in the constitution of area studies, the visualisation of these spaces needs to be carefully considered. Maps are major tools of spatial representation, and the visions, politics, and assumptions underlying them have become an important field of study within human geography (for example, Harley, 1992). Over the past half-century, the scramble for the area has influenced mapmakers as much as the rest of us, and atlases commonly have maps with the captions 'Southeast Asia' and 'South Asia'. These apparently objective visualisations present regional heartlands as well as peripheries-parts of the world that always drop off the map, disappear into the folds of

(8) For a fierce attack and a portrayal of area studies as "idiographic, self-referential, ... anchoring in an anachronistic, positivist, epistemology", see Palat (1996, page 301).

(9) Both areas, which crosscut 'Southeast Asia', gained considerable currency in the late 20th century. Their emergence owed much to Fernand Braudel's ideas regarding the Mediterranean, which Reid $(1988 ; 1993)$ also applied to Southeast Asia. For a programmatic statement on the Indian Ocean area, see Dowdy (1985). Since then, academic journals (such as The Indian Ocean Review) and research institutes (for example, the Centre for Indian Ocean Regional Studies, Curtin University of Technology, Perth) have taken the area as their focus. On the Pacific Rim/Pacific Basin/Asia-Pacific, see, for example, Dirlik (1992). 
two-page spreads, or end up as insets. In this way, cartographic convenience reinforces a hierarchical spatial awareness, highlighting certain areas of the globe and pushing others into the shadows.

For example, anyone interested in finding fairly detailed modern maps showing the region covering Burma, Northeast India, Bangladesh, and neighbouring parts of China knows that these do not exist. This is a region that is always a victim of cartographic surgery. Maps of Southeast Asia may not even include the northern and western parts of Burma, let alone the neighbouring areas of India and Bangladesh. ${ }^{(10)}$ And maps of South Asia not infrequently present Northeast India (and sometimes Bangladesh) as an inconvenient outlier that is relegated to an inset. Odd bits of Tibet and Yunnan may show up in far corners merely because of the need to fill up the rectangular shape of the map.

This is an example of a region that routinely is sliced into pieces by makers of regional maps, a treatment never meted out to 'heartlands' such as Java or the Ganges valley. It is not farfetched to argue that cartographic peripheralisation is indicative of marginal status of an area in area studies, not just in terms of physical distance to some imagined area core, but also in terms of perceived relevance to the main concerns and problematiques that animate the study of the area-in this case Southeast Asia, South Asia, Central Asia, and East Asia, four major areas that supposedly meet here (see figure 1). ${ }^{(11)}$ In other words, this region, like others, is largely excluded from the 'area imagination'. Such regions are subsumed under the scholarly rubric of an 'area' only to be ignored, othered, made illegible. ${ }^{(12)}$

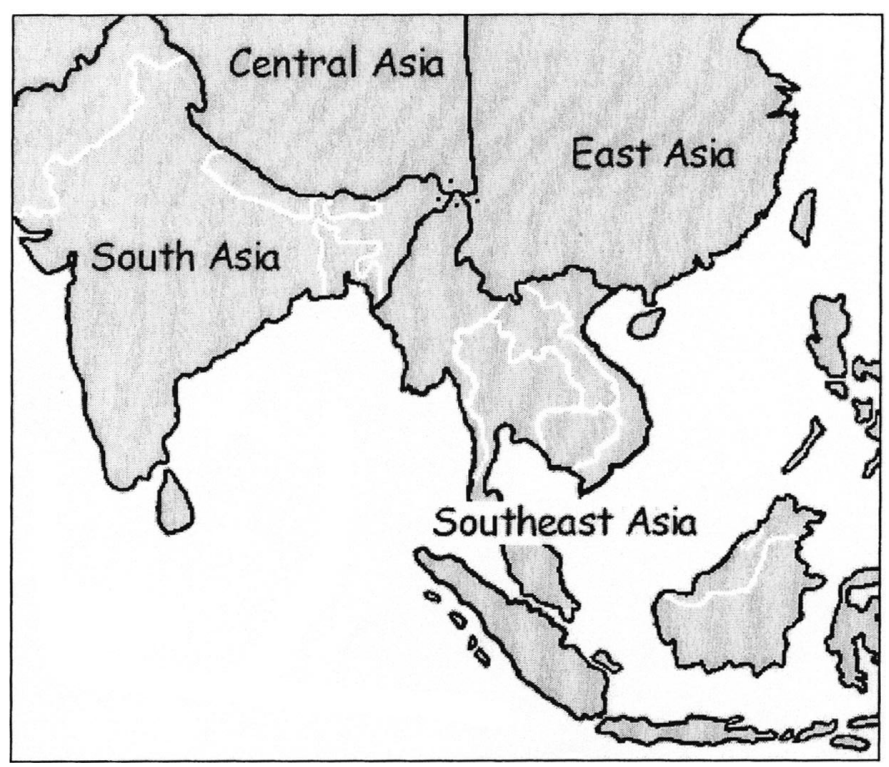

Figure 1. Asia and its areas.

(10) In works on Southeast Asia the maps are not infrequently trimmed to exclude the apparently irrelevant northern reaches of Burma. This tendency is particularly noticeable in maps of 'modern' Southeast Asia. As Southeast Asianists turn from early history to the colonial and postcolonial periods, they appear to become less inclusive and to gravitate towards a 'littoral' persuasion (see, for example, maps in Pluvier, 1974; Rigg and Scott, 1992; Tate, 1971; 1979; Williams, 1976).

(11) Compare with the map in Lewis and Wigen (1997, page 187).

(12) Scott (1998) explores the relationship between power, knowledge, and 'legibility' for states - but the idea of legibility can be applied to other structured groups of observers, such as area specialists. 
It may be useful to highlight the irrelevance of this region to area studies - and the absurdity of area studies for this region-by considering the case of four settlements in the eastern Himalayas, each some $50 \mathrm{~km}$ from the other. Arbitrary decisions made in far-off studies and conference rooms have allocated them to four different world areas: Gohaling is in Yunnan ('East Asia'), Sakongdan in Burma ('Southeast Asia'), Dong is in India ('South Asia'), and Zayü is in Tibet ('Central Asia'). They are represented by four dots in figure 1 . The assumption that the more meaningful links of these places are with faraway 'area cores' rather than with each other is rather preposterous, and the claim of area studies to be mindful of the unity of people's 'shared ideas, related lifeways, and long-standing cultural ties' comes a cropper here.

There is of course nothing specific about Southeast Asian studies in this respect. The very structure of area studies leads to the peripheralisation of certain regions and certain types of knowledge. In the next section, I explore the problem for a nameless region stretching across four current academic areas. Let us give it the name of Zomia. ${ }^{(13)}$

\section{Why Zomia is not an area}

According to the physical-space criterion used to support and legitimate area studies, Zomia certainly qualifies (see figure 2). Its 'shared ideas, related lifeways, and long-standing cultural ties' are manifold. They include language affinities (for example, Tibeto-Burman languages), religious commonalities (for example, community religions and, among the universalistic religions, Buddhism and Christianity), cultural traits (for example, kinship systems, ethnic scatter zones), ancient trade networks, and ecological



Figure 2. An area of no concern: 'Zomia'.

(13) This is derived from zomi, a term for highlander in a number of Chin-Mizo-Kuki languages spoken in Burma, India, and Bangladesh. Linguists classify these languages as belonging to the very large family of Tibeto-Burman languages spoken all over Zomia [Kashmir, North India, Nepal, Tibet, Sikkim, Bhutan, Northeast India, the Chittagong Hill Tracts (Bangladesh), Burma, Yunnan, and Sichuan (China), Thailand, Laos, and Vietnam]. Not unexpectedly, in view of the academic compartmentalisation of this vast region, "with few exceptions these languages are very inadequately described in the scholarly literature ... the chaotic situation which currently exists concerning the mutual relations and affinities among those languages is hardly surprising" (Shapiro and Schiffman, 1983, page 115; compare with http://linguistics.berkeley.edu/stedt/html/STfamily.html). 
conditions (for example, mountain agriculture). ${ }^{(14)}$ In the past, Zomia was a centre of state formation (for example, the Nanzhao kingdom in Yunnan, Tibetan states, the Ahom kingdom in Assam), but today its prime political characteristic is that it is relegated to the margins of ten valley-dominated states with which it has antagonistic relationships. ${ }^{(15)}$ Even though it does not have a pleasing (sub)continental shape, Zomia could have been defined as a distinct geographical region, an object of study, a world area.

But Zomia does not qualify as an area at all if we consider the symbolic-space criterion proposed by Tadiar. It has not been worked up into "a theoretical problematique ... offering new sets of questions and methodologies". On the contrary, it has declined steeply as a theory-generating locus. For example, in the field of anthropology, Zomia was important up to the mid-20th century. It produced influential studies, such as those by Edmund Leach, F K Lehman, and Christoph von FürerHaimendorf, in which the links between kinship, political structure, ethnic identity, and ecology were theorised. Such studies could have formed the basis for an unfolding 'theoretical problematique', comparable perhaps to what developed in Andean studies in the second half of the 20th century. If seas can inspire scholars to construct Braudelian regional worlds, why not the world's largest mountain ranges? But this did not happen. Instead, excellent studies of various parts of Zomia continued to be done, but these did not address an audience of fellow 'Zomianists', not did they have the ambition to build up a Zomia perspective that could offer new sets of questions and methodologies to the social sciences (for some recent work on this region see, for example, Atwill, 2000; Chiranan Prasertkul, 1990; Hill, 1998; Jonsson, 1999; Michaud, 2000; van Schendel et al, 2000; van Spengen, 2000; Walker, 1999; Wijeyewardene, 1990). These studies were written either for disciplinary colleagues who knew little about the region, or for more parochial groups of specialists of, say, Yunnan, Northeast India, or Tibet. If specialists of the four academic 'areas' between which Zomia was divided showed an interest, this was merely an unexpected boon. ${ }^{(16)}$

In other words, Zomia also failed to qualify as an institutional space. No strong transnational scholarly lineages, circles of referencing, or structures of authority and patronage developed around Zomia. Unlike 'Southeast Asia', or other areas that made it academically, 'Zomia', like other would-be areas, lacked an institutionally grounded network for protecting, promoting, and validating area expertise. There appear to have been three main reasons for this.

First, the geopolitics of the Cold War mitigated against the construction of a 'Zomia' because this region straddled the communist and capitalist spheres of influence. Unlike other areas, whose case for research funding in the North could be presented politically

(14) If this comes across as an odd assortment of characteristics, it is good to realise that the traits usually presented to define an area tend to be an "unacknowledged jumbling of physiographical, cultural, and political categories" (Lewis and Wigen, 1997, page 197). In this regard, a claim for 'Zomia' on the basis of the criteria mentioned above is no more farfetched than that for the Middle East, based on 'a 'crossroads' location, aridity, oil wealth, Islamic culture, Arabic language, early contributions to civilization, and a recent history of ferocious strife" (Wheeler and Kostbade, 1993, page 196); for a critical review, see Lewis and Wigen (1997, page 197, compare page 195).

(15) The only exception is Bhutan, in which state power formally lies with a Zomia elite, but this elite is heavily controlled by the state elite of India. The ten states are China, Vietnam, Laos, Cambodia, Thailand, Burma, India, Bangladesh, Bhutan, and Nepal.

(16) Within Southeast Asia studies, an attempt is currently under way to make the case for a 'montagnard [mountain dwellers] domain'. In their review of the literature, McKinnon and Michaud (2000, page 2) show that there are studies for single cases but hardly any which address "more than one mountain society of the [Mainland Southeast Asian] Massif and giv[e] the latter the status of a coherent supra-national spatial and social unit." 
as either 'knowing your enemy' or 'guiding young nations toward democracy', Zomia was a confusing region, and politically not a sufficiently threatening one to merit a great deal of attention.

Second, Zomia did not cover important states but only politically marginal regions of states. This was a severe handicap because area studies, for all their culturalist language, are firmly statist in their orientation. All successful areas have been constructed on the basis of groups of mid-20th-century states, or even on alliances of such states. ${ }^{(17)}$ State borders are conventionally used to demarcate the outer boundaries of each area. ${ }^{(18)}$ Most area specialists think in terms of nation-states and identify with the state level and particular state-bounded societies (compare, Reynolds and McVey, 1998). To the outside world they present themselves as Indonesianists rather than, say, insular Southeast Asianists or Kalimantanists. The languages taught to budding area specialists at Northern universities are the 'national' languages of states. ${ }^{(19)}$ The state level not only takes priority in conceptual terms but is also inescapable in terms of funding, institutional visibility, and international networking. This is an important reason why Zomia, an area without independent states, never stood a chance. ${ }^{(20)}$

To make things worse, in the second half of the 20th century much of Zomia resisted the projects of nationbuilding and statemaking of the states to which it belonged. In these projects, uplanders were often excluded from discourses of citizenship, and cast in the roles of nonnationals, alien elements, or poachers of the state's forestry resources who could be redeemed only by assimilating to the lowland 'mainstream' (see Jonsson, 1998). All over Zomia, states implemented policies of population relocation, prevention of hill agriculture, land registration, logging, wildlife protection, dam building, watershed protection, and education in national languages, which led to new forms of competition and tension. Such forms of 'development' did not act as an antipolitics machine (Ferguson, 1990). On the contrary, Zomia became characterised by a high incidence of regionalist and separatist movements, 'nonstate spaces', and discursive battles around concepts such as 'tribe' and 'indigenous people' (Scott, 2000). Some of these movements were picked up by the world media (which turned Tibet,

(17) Many Southeast Asianists tacitly limited their scope to the ASEAN (Association of Southeast Asian Nations) countries (which for decades excluded Laos, Burma, Vietnam, Cambodia, and East Timor), as did South Asianists later with the SAARC (South Asian Association for Regional Cooperation) countries. Areas with 'insufficient statehood' have difficulty establishing themselves as scholarly areas-for example, 'Central Asia', which could not emerge as an area until it developed independent statehood in the form of the post-Soviet states of the region.

(18) Often there are curious inconsistencies. Tarling's (1961, page xi) definition of the area seemed straightforwardly statist: "The term 'Southeast Asia' is used to describe a group of states which lie between the great land masses of India and China". But, when it came to the list of territories, he included not only eight states, but also the Andaman and Nicobar Islands (which belong to India). (19) The ambitious and successful SEASSI (Southeast Asian Studies Summer Institute) languageteaching programme in the USA is a good example. Here, Vietnamese, Tagalog, Lao, Khmer, Thai, Indonesian, and Burmese are taught; these are all state languages. In addition, out of hundreds of nonstate languages in Southeast Asia, two can be learned here: Hmong and Javanese. Most South Asian area studies cannot match this richness. They tend to concentrate on two state languages of the region, Hindi and Urdu (but do not offer the state languages of Nepal, Bangladesh, Bhutan, Sri Lanka, or the Maldives), and two 'classical' languages, Sanskrit and Tamil.

(20) The low level of Zomia's 'state visibility' is also reflected in the longtime absence of any state alliances across the region. There were no ASEANs, SEATOs, or SAARCs. It was not till the 1980s that the first state-sponsored initiatives materialised, for example, ICIMOD (The International Centre for Integrated Mountain Development), launched in 1983 and concerned with networking across Zomia. Its initial focus on the Hindu Kush, in the Himalayan region, has gradually been widened through the Asia-Pacific Mountain Network (see http://www.icimod.org/). 
Kashmir, and the Golden Triangle into household names), but most remain largely unknown even to area specialists. ${ }^{(21)}$ For example, the average South Asianist would be hard-pressed to give an informed analysis of the dozens of highly active autonomy movements in Assam and other northeastern states of India, some of them over fifty years old.

As a result of this antagonistic relationship and the weakness of state control over large areas of Zomia, several of these states have severely restricted the ingress of outsiders. ${ }^{(22)}$ In this way, state marginality also mitigated against a blossoming of Zomia area studies. Area specialists who had worked freely in the region in the 1940s and 1950s found it increasingly difficult to get access for themselves and their students in more recent decades. Although these restrictions were not uniform and now appear to be lessening in most parts of Zomia, this history of difficult access, state surveillance, and physical danger has proved a setback to the study of the region.

Third, Zomia lacked the support of two influential university-based groups that were instrumental in building up academic area studies in the North. One group consisted of 'colonial experts' - intellectuals in charge of erstwhile training courses for colonial officials, as well as their trainees-who were looking for new roles at the end of the colonial era. Many of them sought to reinvent themselves as area-sensitive development specialists, and they strongly supported the repackaging of their knowledge and skills in the form of area studies. The other group was that of 'civilisational specialists', scholars who studied non-Western 'civilisations', especially through their textual legacies, and were known as Indologists, Islamologists, Sinologists, or, more generally, Orientalists. These experts were keen to make sure that any new area studies were built around the civilisational constructs to which they devoted themselves. In the case of 'South Asia' and the 'Middle East', colonial experts and civilisational specialists partook in almost equal measure in the creation of their 'area', whereas in the case of 'East Asia' the civilisational specialists dominated, and in that of 'Southeast Asia' the colonial experts dominated. Southeast Asianists were acutely aware that civilisational specialists gave indispensable prestige to an 'area' and they were keen to point out that, even though few civilisational specialists considered their 'area' to be one of the world's great civilisations, "the cultural traditions of Southeast Asia are too rich and too dynamic to be afterthoughts in fields devoted to the 'great' traditions of the world" (Keyes, 1992, page 18). (23) And unlike, for example, South Asia, Southeast Asia remained a weakly constructed area because it did not develop strong local roots:

"Southeast Asia is not, generally speaking, a domain meaningful for study in countries within the region, where national histories are of primary concern, and

(21) Some area specialists have followed what Wolters (1999, pages 160-162), in an interesting piece of self-criticism, calls the "conceit of the lowland's elite" and the "lowlanders' prejudice" regarding the uplands, which are perceived as distant, isolated hinterlands with a lowly status in the world order.

(22) For example, India retains the colonial 'Inner Line Regulation' that bars the entry into Northeast India (that is, the states of Assam, Meghalaya, Sikkim, Arunachal Pradesh, Tripura, Mizoram, Manipur, and Nagaland) of not only foreign nationals but also nonlocal Indians, including researchers (see Chakraborty, 1995; Robb, 1997).

(23) Southeast Asianists have sought to explain why their region was a latecomer among world areas. Anderson (1998, pages 4-5) gives four reasons for this: the absence of a historic hegemonic power, religious heterogeneity, a segmented history of imperialism; and a position as being most remote from imperial centres. In the region, he suggests, a sense of unity was formed by three factors: Japanese occupation during World War 2, the armed fight against imperialism, and the Cold War experience, in which Southeast Asia was the most unstable region for the USA, which feared communist takeovers here. 
has been mostly a Euro-Japanese construct” (Reynolds, 1995, page 420; compare Tarling, 1999, page xviii). ${ }^{(24)}$

But Zomia was more disadvantaged than that. It was an inland region that had been at the margins, or even beyond the effective scope, of an external influence that animated lively debates in South Asian and Southeast Asian studies: maritime European colonial conquest. Zomia lacked a strong lobby of colonial experts. Also it had not developed a powerful civilisational persona in Northern universities, because it also lay at the margins or beyond the 'civilisational' impact of India, China, and Islam. And therefore it had very few civilisational specialists to fend for it.

As a result of these three handicaps - political ambiguity, absence of strong centres of state formation, and insufficient scholarly clout-prospective Zomianists lost out in the scramble for the area after World War 2. They were unable to create a niche for themselves and for the social relations and networks that they studied. As their region was quartered and they were prevented from intellectually reproducing themselves, the production of knowledge about this region slowed down and the new area dispensation defined their work as less consequential. Fifty years later, these handicaps persist, even though the geopolitical visibility of Zomia changed somewhat with the emergence of large-scale heroin production in the area, the discovery of mineral resources, tourism, and a new concern with environmental and indigenous issues. But these changes were not enough to undo Zomia's marginal place in the hierarchy of knowledge, or to revive knowledge production, let alone give support to viable claims to areahood. ${ }^{(25)}$

\section{The scale of area studies}

The example of Zomia shows that the area studies that developed during the Cold War were not quite what they appeared to be: joint enterprises by practitioners of the social sciences and the humanities to advance thoroughly grounded comprehensive knowledge of the different regions of the world. They were both more and less. As expressions of a particular geography of power, they were instruments to naturalise the geopolitical arrangements of the day. As expressions of certain academic interests and disciplines, they were instruments in institutional strategies with regard to funds, students, jobs, and prestige. And they contributed to a certain ghettoisation of critical insights as area studies tended toward the guild model. Area specialists were rewarded for 'knowing their proper place': training in area studies centres, recognising differences within the larger context of their area's unity, offering their findings to areafocused seminars and journals, and devoting their careers to the study of their area of training, without necessarily keeping abreast of intellectual developments next door.

The powerful geographic imagery of area studies emphasised contiguity or physical closeness in social analysis and suggested a certain homogeneity across each area that could be projected back into time. This rhetoric, freely used to legitimate area studies, was rarely put to the test. A fundamental problem is that area studies have produced many 'subregional experts' (to use a term employed by Wolters, 1999, page 213) but

(24) More recently, Anderson put it like this: "As a meaningful imaginary, [Southeast Asia] has had a very short life, shorter than my own. Not surprisingly, its naming came from outside, and even today very few among the almost 500 million souls inhabiting its roughly 1,750,000 square miles of land (to say nothing of water), ever think of themselves as 'Southeast Asians"' (1998, page 3).

(25) In recent years, prominent Southeast Asianists have repeatedly portrayed their field as weakened, relatively invisible and academically marginalised. It is good to keep a sense of perspective here. When Southeast Asianists describe their region as "the most insubstantial of world areas", they obviously do not have regions such as Zomia or Central Asia in mind. Similarly, when they worry about a threatening "generation gap" in Southeast Asian studies, it is sobering to compare this with the veritable "generational chasm" which has opened up in the study of Zomia (Weighing the Balance 2000, pages 13, 14, 16). 
remarkably few true area specialists: scholars with a thorough grasp of the entire area of their choice. Instead, certain well-researched subregions and themes inevitably came to be portrayed as somehow embodying the essence of the area, and therefore capable of being presented as partes pro toto. In this way, area studies were a great boost to the study of these subregions and themes but did little for others, effectively making these less visible. As an imagery, then, the area was much more meaningful to certain concerns, comparisons, and interests than to others. ${ }^{(26)}$

Today, the important issues no longer seem to be the search for the cultural grammar of Southeast Asia, the essence of Islamic civilisation, or the spirit of East Asia. Such essentialist queries do not sit easily with the fascination with hybridity, transnationalism, and global transformation that has animated so many recent research projects. Geographical compartmentalisation has become a drawback. Calls can be heard to overcome the "contiguity fetish of prevailing regional schemes" and to:

"visualize discontinuous 'regions' that might take the spatial form of lattices, archipelagos, hollow rings, or patchworks ... the friction of distance is much less than it used to be; capital flows as much as human migrations can rapidly create and re-create profound connections between distant places. As a result, some of the most powerful sociospatial aggregations of our day simply cannot be mapped as single, bounded territories .... The geography of social life in the late twentieth century has outgrown not only the contours of the postwar world map, but also the very conventions by which we represent spatial patterns in image and text" (Lewis and Wigen, 1997, pages 190, 200).

In other words, what is being advocated is "a decisive shift away from what we may call 'trait' geographies to what we could call 'process' geographies", which retain the heuristic impulse behind imagining areas but treat them as contingent and variable artifacts (Appadurai, 2000, page 7). This concern to rethink the spatiality of social life can benefit from recent contributions that criticise the social sciences for their widespread practice of treating space as "self-evident, unproblematic, and unrequiring of theory", and of seeing "history as the independent variable, the actor, and geography as the dependent - the ground on which events 'take place', the field within which history unfolds (Smith, 1992, pages 61, 63).

Rejecting spatial categories as ontologically given - as static, timeless containers of historicity (Brenner, 1999, page 46) - theorists in human geography are in the process of developing a theory of geographical scale. ${ }^{(27)}$ They emphasise that the different scales, or levels of spatial representation, that we use in our social analyses-for example, local, national, regional, global-are in no way pregiven but are socially constructed and should be understood as "temporary stand-offs in a perpetual transformative ... socio-spatial power struggle" (Swyngedouw, 1997, page 169). ${ }^{(28)}$

(26) One of these concerns was to construct an area identity in addition to, or in opposition to, the national identities strongly being promoted during the same period (for Southeast Asia, see Emmerson, 1984, page 21). Both nationalists and area specialists used history as a powerful tool in this endeavour. Hence a book title such as The History of Southeast Asia comes across as equally programmatic as, say, that miracle of invention, 5000 Years of Pakistan. The endeavour of area studies over the last half-century is perhaps best summed up in another book title, In Search of Southeast Asia: A Modern History.

(27) An important source of inspiration for this approach is the work of Lefebvre (especially 1976-78; 1991). For an overview, see Marston (2000).

(28) "These struggles change the importance and role of certain geographical scales, reassert the importance of others, and sometimes create entirely new significant scales, but-most importantly - these scale redefinitions alter and express changes in the geometry of social power by strengthening power and control of some while disempowering others" (Swyngedouw, 1997, page 169). 
Asserting that scales are always provisional geographical resolutions of power struggles, they invite us to consider how these are historically produced, stabilised, and transformed. ${ }^{(29)}$ Clearly, scalar configurations — or 'scalar fixes' (Smith, 1995) — can be quite long-lived, and they can become so stabilised as 'scaffoldings' of certain forms of power and control that we experience them as natural and permanent. But they are always finite. ${ }^{(30)}$

As we have seen, the 'world region' or 'area' is a relatively new scale, at least as a spatial representation that is imagined to be a component of a continuous grid spanning the globe. It is also a contested one. The constructionist approach to scale outlined above can help in studying more systematically what geometries of power went into the 'rescaling' that produced the configuration of area studies after World War 2. At the same time, this endeavour may help to broaden the theory of geographical scale in three ways.

First, although it is recognised that "geographical scales are produced, contested, and transformed through an immense range of sociopolitical and discursive processes, strategies, and struggles that cannot be derived from any single encompassing dynamic" (Brenner, 1998, page 461), theorists of scale have so far focused their attention overwhelmingly on the role of capitalist production and the state in the construction of scale. ${ }^{(31)}$ The construction of area studies, however, appears to have occurred relatively independently of the agency of capital, labour, and the state. For this reason, the construction of area studies may provide a good case for exploring the significance, in processes of rescaling, of sociocultural and discursive factors in addition to socioeconomic ones.

Second, theorists of scale have studied certain scales more than others. The urban, national, and global scales have received most attention, with recent contributions calling attention to the household and the body. But the scales between the national and the global remain underexposed, and here the scale of world regions is a useful field of further inquiry.

And third, the theory of the social construction of scale is still strongly North Atlantic and urban in flavour. It deals with highly industrialised ('core') societies and takes its case studies from Europe and North America, that is, from only one or two 'world regions'. Such selectivity may be read as a particular example of the 'politics of scale' to the extent that it conveys implicitly that it is industrial capitalism, powerful bureaucratic states, and 'Western' constructions of scale that matter most (for a rare exception, see Kelly, 1997). This is exactly what many practitioners of area studies have long questioned. It is essential for a theory of scale to take into account the many ways in which politics of scale emanating from various parts of the world have shaped our contemporary condition. As an era of Euro-US imagining of the world's regions comes to an end,

"actors in different regions now have elaborate interests and capabilities in constructing world pictures whose very interaction affects global processes. Thus the world may consist of regions (seen processually), but regions also imagine their own worlds" (Appadurai, 2000, page 10). ${ }^{(32)}$

What is needed, then, is a new sociospatial lexicon to enable us adequately to analyse these developments (Lewis and Wigen, 1997, page 192). The geographical metaphors of

(29) As Howitt (1998) argues, it is crucial to understand scale as relation, and not merely in terms of its size and level.

(30) For a schematic history of scalar fixes since the late 19th century, see Brenner (1998).

(31) For a first attempt to incorporate social reproduction and consumption, see Marston (2000).

(32) Kelly asserts that in the Philippines such alternative imaginations of the global do exist, although largely beyond the bounds of institutional politics (1997, page 169). 
area studies have been used to visualise and naturalise particular social spaces as well as a particular scale of analysis. An important question is how such metaphorical spaces relate to material space. To what extent have they resulted in a methodological territorialism that analyses spatial forms and scales as being self-enclosed and territorially bounded geographical units (Brenner, 1999, pages 45-46)? What geographies of knowing have resulted from area studies? And what geographies of ignorance?

In this paper, I have noted that area specialists have been quite unconcerned with what their metaphors make invisible. I have done so by invoking a material space (Zomia) that has been rendered peripheral by the emergence of strong communities of area specialists of South, Central, East, and Southeast Asia. ${ }^{(33)}$ Without doubt, the question of invisibility can best be approached from Southeast Asian studies because these have produced such an introspective, soul-searching literature about themselves-by comparison, other area studies are much more complacent. ${ }^{(34)}$ But even Southeast Asianists are little concerned with exploring how their geographical metaphor determines how they visualise space and what they cannot see. There are, to my knowledge, no spirited debates about the effects of privileging 'heartlands', the precise demarcation of the area, the delimitation of its farthest reaches, or the need to explore and encompass its margins. On the contrary, the debonair way in which foundational texts treat such matters suggests perhaps that precise demarcation is considered to be both pedestrian and pedantic. But it may be worthwhile to take the geographical intent of area studies more seriously and consider other perspectives that may turn areas 'inside out' [to use a term employed, in a somewhat different fashion, by Wyatt (1997)]. An examination of the geographical notion of distance may be particularly helpful in opening up new lines of research.

\section{Distant places}

The idea of remoteness was of course important in the creation of area studies as these were faraway places that needed to be understood better in the world centres of power. Distance was both a physical reality and a cultural metaphor, and area studies offered geographies of long-distance knowing. Half a century later, technologies of communication have changed the picture. Distance is no longer quite the tyrant it once was, and an acute awareness of the shrinking of the world has spread widely, if unevenly, around the globe. This is true not only between regions of the world but also within them [for the tremendous shortening of travel times in the Burma-China borderland since the mid-1980s, see Porter (1995, pages 36-40)]. Much is being written about the ways in which new technologies of transport, media, and digital networking forge new communities both locally and globally and how these can be studied adequately only by looking at networks that are not contained within the bordered territories of states and areas. Distance is no longer understood primarily in geographical and cultural terms. It is increasingly seen as a social attribute: certain groups of people have better access to technologies to overcome distance than others.

Area studies and their problematiques are ill suited to deal with human relations spilling over area boundaries, and we have to devise more adequate perspectives to encompass these. Although globalisation studies emphasise the growth of worldwide networks (new media, capital flows, diasporas, international organisations, the 'global

(33) This peripheralisation is less prominent among area specialists concerned with the archaeology and early history of Asia but becomes more so among specialists with an interest in recent history and the contemporary period. Jonsson (1998) argus that the invisibility of uplanders in Southeast Asian studies has also resulted from trends in anthropological theorising that privilege rulers and peasants as political and economic protagonists.

(34) Debates on the usefulness of the construction of particular areas occasionally do flare up, for example, the brief altercation on the Mediterranean between Pina-Cabral (1989) and Gilmore (1990), or Ascherson's (1995) portrait of the Black Sea. 
city'), there are many other border crossings that need to be understood. It is a mistake to assume that the most revealing crossings are those between the West and the rest. Understandings of global linkages need to emerge forcefully form direct exchanges between scholars studying different parts of the 'South'.

A major task in the restructuring of the world academy in the early 21 st century is the building up of institutions that allow academics trained in the study of a particular area to overcome such boundaries and to communicate more meaningfully across them at all levels: the production of theoretical knowledge, thematic focus, methodology, empirical skills. We need academic versions of the strategy of "jumping scales" (Smith, 1992, page 60), which allows us "to circumvent or dismantle historically entrenched forms of territorial organization and their associated scalar morphologies" (Brenner, 1999, page 62). ${ }^{(35)}$

\section{Crossing regional borders}

Area specialists regularly assert the need for 'border crossings', in order to highlight interregional linkages rather than regional identities, but it is rare for these calls to be translated into lasting institutional arrangements that make for innovative cross-regional collaboration (for example, Volkman, 1998). Academic centres of area studies can be remarkably inhospitable places for specialists of other areas, and cross-regional collaboration is almost never high on their agenda. Collaboration in the form of cross-regional projects does occur however, for example, between Southeast Asia and East Asia and between Southeast Asia and the Pacific Rim.(36) Such geographies of cross-regional knowing are much weaker, or even absent, between specialists of Southeast Asia and Central Asia, or Southeast Asia and South Asia. ${ }^{(37)}$

Two themes appear to be especially useful in initiating meaningful academic collaboration on interregional linkages. Both have to do with perspectives on space, distance, and mobility - with the conceptual maps we use to order social life. The first is borderlands, the second is flows of objects, people, and ideas.

\section{Borderlands}

The outer reaches of 'areas' are less well known because most research has been concentrated on problematiques dealing with what are perceived to be heartlands and centres of power and change. ${ }^{(38)}$ Today, as social scientists are distancing themselves from the spatial framework that Eric Wolf once dubbed "a world of sociocultural billiard balls" and are taking cognizance of the processual nature of all geographies of social life, such 'heartlands' and 'centres' look increasingly contrived [(Wolf, 1982,

(35) In the pursuit of politics of scale, groups of people often jump scales by organising at a more global scale, but jumping scales may also lead to mobilisation at a more local scale (compare Cox, 1998).

(36) For example, the Thai - Yunnan Project set up at the Australian National University in 1987, or the research programme 'International Social Organization in East and Southeast Asia: Qiaoxiang ties in the 20th century', initiated by the International Institute of Asian Studies in The Netherlands in 1997.

(37) In this respect, academics appear to be well behind the political times. Take, for example, state-tostate networks, which long seemed to fit the regional mode but increasingly reach across area borders to form multistate economic-production and trade networks (growth triangles, quadrangles) and multistate infrastructures (Asian Highway, Trans Asian Railway, reopening of the Stillwell Road from Assam to Yunnan). These are examples of a whole range of distances between the 'local' and the 'global' that need to be explored both conceptually and empirically. See Sobhan (1999; 2000) on the BBIMN (Bhutan, Bangladesh India, Myanmar, Nepal) growth zone and cross-regional transport, and Carter (1999) on the China - Burma growth zone.

(38) In this sense, area borderlands are as remote to an area specialists as 'unadministered areas' were to colonial officials (see Means, 2000). 
page 17; for an analysis of the fragmentation of an industrial heartland in the USA, see Smith and Dennis (1997)]. And as political power is seen more in terms of everyday social practices than as primarily embodied in the institutions and processes of formal politics, conventional ways of studying states, nations, and societies are under review. (39) A burgeoning literature on international borderlands suggests that much can be learned about centres of power by looking at their peripheries. Many issues that currently hold the attention of social scientists - transnationalism, citizenship and othering, ethnic accommodation, hybridity, the interpretation of scales and regulatory practices, underground economies, and international conflict-have always been integral to borderland milieus (Baud and van Schendel, 1997; Donnan and Wilson, 1999; Martínez, 1994).

In social science research, the longstanding tendency has been to view named units (states, societies, and cultures) as separate and distinct, each with its own internal structure and external boundaries. Late-20th-century thinking in terms of separate 'areas' has followed that example. But areas are even less like billiard balls than states are. The focusing of more research on what area specialists have learned to think of as the borderlands of their area may help to overcome what their geography of knowing has obscured and marginalised: the many interconnections between these dynamic bundles of relationships. Current attempts at refashioning area studies are beginning to pick up on this. They present the borderlands between areas as "interstitial zones" that function "almost like hybrid regions in their own right" (Lewis and Wigen, 1997, pages 188,203$)$.

\section{Flows}

A promising way of developing a historically more complete and theoretically richer sense of the interconnections between areas is to start from objects and people in transnational (or 'transareal') movement. We are aware of the enormous importance of transnational mobility but still lack the concepts, theories, and measures to study them adequately. Even something as straightforward as the size of these flows is often unknown, especially the size of those commodities that are declared illicit by some, or all, states. To give just one example, the world trade in illegal drugs has been guesstimated at anywhere between $\$ 500$ and $\$ 1000$ billion a year, that is, roughly the same size as the combined GNP of all the states of Southeast Asia. ${ }^{(40)}$ If we add to this other illicit flows (traffic in small arms, undocumented labour, nuclear materials, animals, human organs, works of art, and so on), as well as the flows that show up as world trade in national and international accounting, we may begin to get a sense of the role of flows in the creation of process geographies.

As these flows move through localities, contributing to their rise and fall, they interact with states and nonstate organisations. The resultant patterns of interaction are complex and change over time. States may outlaw certain flows, giving rise to subversive economies, or they may encourage them, giving rise to state-nonstate alliances. Flows may suddenly change course as a result of events such as war, economic crisis, or collapsing consumer demand. In any case, transnational flows, and the networks, movements, enterprises, and organisations that promote them, weave in and out of the arenas that area specialists have created for themselves.

(39) As McVey (1978, page 3) noted, historians have turned their attention to "the lower levels of society both as intrinsically significant arenas of experience and as essential base-points for understanding social change". This attention can be extended by focusing more systematically on arenas of experience away from the area heartlands as currently defined.

(40) The United Nations Conference on Global Organised Crime (1994) put forward the estimate of about $\$ 500$ billion a year but other reputable estimates put the correct figure at twice that amount. The GNP of all of Southeast Asia in the same period has been estimated at around $\$ 700$ billion. 
Mapping these flows can only be done properly by engaging the expertise of specialists of more than one area, but, on the other hand, area specialists need to develop a new sociospatial lexicon in order to communicate effectively with each other regarding flows.

The study of area borderlands sometimes overlaps with that of transnational flows, and it may be particularly rewarding to focus fresh inquiries on this meeting ground. In the case of the northern borderlands of Southeast Asia, new research can build on some earlier efforts, mainly concentrated on the region where Yunnan and 'mainland Southeast Asia' meet (for example, Vorasakdi Mahatdhanobol, 1998; Wijeyewardene, 1993). One approach that has been developed here is that of analysing flows at borders in terms of a politics of mobility - a meeting of regulatory practices used to initiate and control mobility and interconnection. As Andrew Walker demonstrates in a recent study of traders on the Mekong River, it is territorial states that meet at borders but the regulation of transnational flows is not just the domain of states. Nonstate actors are active participants in a politics of mobility that may encourage or hamper flows of goods and people across state (and 'area') borders (Walker, 1999).

By contrast, the northwestern borderlands have been neglected by students of both South Asia and Southeast Asia, and are now among the least known regions in the world. And yet, considerable transnational flows pass through here. Most have been prohibited by one or more of the states concerned, and are therefore at least partly underground. Among the most visible are small arms and explosives, heroin and the chemicals needed to produce it, and labour migrants, guerrilleros, and refugees. ${ }^{(41)}$ The ways in which states interact with these flows - by large-scale militarisation, transmigration programmes, crop substitution, taxation, and so on - and the ways in which these flows interact with statesby percolating through their bureaucracies, forging links with state power holders and influencing their policies - are often most visible in border regions.

Clearly, 'state' and 'area' are too limiting as scales if we wish to analyse transnational flows. In addition to the fact that flows do not respect these scales, struggles over the regulation of flows are continually influencing scales, changing their relative importance, or creating entirely new ones (compare, Swyngedouw, 1997, page 169). Such 'process geographies' in the making can be observed well at borders. Take the flow of small arms across the borderland of South and Southeast Asia. The borderland itself is associated with numerous armed rebellions, and they, and the state armies opposing them, use assault rifles, submachine guns, and rocket launchers produced in the United States, Russia, Israel, or Belgium. ${ }^{(42)}$ But arms are also used to protect illicit flows of heroin and many other commodities as they pass the border on their way to far-flung markets. Social scientists have little information about arms flows in

(41) Decades of insurgency in northwestern Burma, northeastern India, and southeastern Bangladesh have made the region a longstanding arms market with major supply routes through Thailand, China, and the Bay of Bengal (via Bangladeshi ports). Heroin from the Golden Triangle is used to supply a rapidly expanding consumer market in South Asia. In recent years, many heroin refineries have been moved from the Thai-Burma border (Shan State) to the India-Burma-Bangladesh borders (Chin State), and South Asian ports and airports are now increasingly being used to ship heroin to European markets. Population movements in the region are quite large: millions of Bangladeshis have moved illegally into northeastern India in search of work and land, refugees and labour migrants from Burma have moved to India and Bangladesh (and, further afield, Rohingyas from Burma now form large communities in Bangladesh, Pakistan, and the Gulf). And insurgents from all countries in the region habitually move across borders, hiding from security forces, swapping money or drugs for arms, and establishing alliances with foreign powers.

(42) Insurgent groups along the border between 'Southeast Asia' and 'South Asia' include Arakanese, Jumma, Chin, Meithei, Naga, and several other groups fighting for regional autonomy or independence from India, Burma, and Bangladesh. 
the region, and we know even less about how these reshape regulatory practices at borders, or rescale states in this region. The westward flow of small arms through mainland Southeast Asia is documented to some extent (Pasuk Phongpaichit et al, 1998, pages $127-154$ ), and, in a recent world survey of small arms, Bangladesh was identified as an important small arms depot for South Asia and Southeast Asia:

"Bangladesh is a major transit point for arms in the region. Small arms come across

to Bangladesh from Afghanistan and Pakistan on the one side, and from Thailand,

Singapore, Myanmar, and Cambodia on the other. From there, the weapons usually go north to rebels in India's north-east or south to the LTTE [in Sri Lanka] (Small Arms Survey 2001, page 182). ${ }^{(43)}$

But the use of the state, or indeed the 'area', as the scale of analysis for flows hardly helps to encompass the relevant relationships. It is in particular localities of the Bangladesh borderland that these transfers occur, and it may be more helpful if we focus on 'regimes of regulation', the regulatory practices that create these localities. For example, the insignificant border town of Teknaf and the nearby fishing port of Cox's Bazar in southeastern Bangladesh have developed into a major node in a transnational network of arms dealing. They receive arms and ammunition from Burma and from overseas, and route them to destinations in India, Bangladesh, and beyond. What politics of mobility, and what regulatory practices, have combined to single out these two localities? What new geometries of social power emanate from them, and how do these contribute to processes of rescaling, empowering some and disempowering others? These are the types of questions that may lead us to answers about process geographies in the making.

\section{Lattices, archipelagos, hollow rings, and patchworks?}

If we are indeed moving from trait geographies to process geographies in which regions may take unfamiliar spatial forms - lattices, archipelagos, hollow rings, patchworkswe must consider what future there is for the study of conventional areas such as 'Southeast Asia'. In response to the challenge of global perspectives, a rethinking of 'regional' systems of knowing is under way. The social spaces imagined by area studies and the scale of area studies are being reexamined as the spatialisation of social theory enters a new, uncharted terrain. The more we become aware of the ways in which contemporary life eludes conventional assumptions of territorially shared ideas and lifeways, the more such assumptions are also being challenged for the past. And the more we realise how social forces from 'marginal' spaces can resist, and even rearrange, established power structures, the more we must relinquish the heartlandism and state-centredness inherent in the practice of area studies.

Clearly, area studies are not going to be abandoned. There is no doubt that the strong academic communities built around area studies will continue to produce high-quality knowledge about area problematiques. But who will find these problematiques relevant? Will future scholars regard them as expressions of some passé traitism, or perhaps as forms of an early-21st-century Orientalism? Surely, the strength of area studies is their insistence on the specificity of spatial configurations. But their weakness is the imposition of spatial boundaries that make no sense except possibly from a heartland point of view. In order to overcome the resulting geographies of ignorance, we need to study spatial configurations from other perspectives as well. As the scalar fix established after World War 2 is being transformed, the world is being reterritorialised and it is necessary to reimagine emergent spatial configurations between the national and the global. The suggestions made in this paper point to three possible alternatives.

(43) LTTE is Liberation Tigers of Tamil Eelam, the secessionist organisation fighting for a Tamil homeland in northern and eastern Sri Lanka. 
First there is the construction of regions crosscutting the conventional ones. This approach is innovative insofar as it brings together spaces and social practices that are now academically marginal and partitioned. But this approach is also likely to replicate the distortions of area studies by creating new heartlands and margins, as well as communities of scholars who tend to stay within their new arenas. A second option is to look for spatial configurations that are not compact territories. The study of borderlands provides us with a worldwide honeycomb of contiguous material spaces with very distinct social configurations but no particular heartland. This combination of spatial specificity and global coverage makes borderlands a world region of a different kind, and studying it properly requires the involvement of scholars of all conventional 'areas'. The third option goes further. Transnational flows do form spatial configurations but their architecture is more ephemeral: it changes, sometimes rapidly, in size, compactness, and complexity.

The study of these flows, especially the ones driven underground by state prohibition, is notoriously difficult, even if anchored to specific points in space or time. It is here that area expertise is absolutely indispensable for 'flow studies': it can provide the study of flows with a thorough grounding in specific spaces and times. In turn, the study of process geographies (and the regulatory practices that consolidate and dissolve them) will help area specialists to jump scale, to break out of the chrysalis of the area dispensation which occurred after World War 2, and to develop new concepts of regional space.

Meanwhile, back in Shillong, you have finished your lunch-cooked by an illegal immigrant from Nepal and served on plates smuggled in from China. Take a Hindi newspaper from the counter and read about assault rifles coming in from Bangladesh, the price of Burmese rubies, a woman from Shillong who made good in Canada, and last month's drug deaths. The song on the radio has stopped and an announcement is made about the celebration of India's Republic Day. Two young women at the next table snigger and dig into their Thai noodles. You walk out into the sun, wondering about spaces, scales, and flows.

\section{References}

Agnew J, 1999, "Regions on the mind does not equal regions of the mind" Progress in Human Geography 23 91-96

Anderson B, 1998 The Spectre of Comparisons: Nationalism, Southeast Asia, and the World (Verso, London)

Appadurai A, 2000 Globalization and Area Studies: The Future of a False Opposition (Centre for Asian Studies Amsterdam, Amsterdam)

Ascherson N, 1995 Black Sea (Jonathan Cape, London)

Atwill D, 2000, "Reorienting the 'Yunnan world': shifting conceptions of ethnicity, boundaries and trade", paper for the workshop "Beyond Borders: (II)licit Flows of Objects, People and Ideas", Centre d'Études et Recherches Internationales, Paris, 1-4 July

Baud M, van Schendel W, 1997, "Toward a comparative history of borderlands" Journal of World History $8211-242$

Brenner N, 1998, "Between fixity and motion: accumulation, territorial organization and the historical geography of spatial scales" Environment and Planning D: Society and Space 16 $459-481$

Brenner N, 1999, "Beyond state-centrism? Space, territoriality, and geographical scale in globalization studies" Theory and Society $2839-78$

Carter G F, 1999 China's Southwest and Burma's Changing Political Geography (1979-1996) (University Microfilms International, Ann Arbor, MI)

Chakraborty P, 1995 The Inner-line Regulation of the North-east (Together with the Chin Hills Regulation Etc. and with Commentaries) (Linkman Publication, Titagarh)

Chiranan Prasertkul, 1990 Yunnan Trade in the Nineteenth Century: Southwest China's CrossBoundaries Functional System (Institute of Asian Studies, Chulalongkorn University, Bangkok) 
Christian D, 1994, "Inner Eurasia as a unit of world history" Journal of World History 5173 - 211

Cox K R, 1998, "Spaces of dependence, spaces of engagement and the politics of scale, or: looking for local politics" Political Geography $171-23$

Dirlik A, 1992, "The Asia-Pacific idea: reality and representation in the invention of a regional structure" Journal of World History 3 55-79

Donnan H, Wilson T M, 1999 Borders: Frontiers of Identity, Nation and State (Berg, Oxford)

Dowdy W L, 1985, "The Indian Ocean region as concept and reality", in The Indian Ocean: Perspectives on a Strategic Arena Eds W L Dowdy, R B Trood (Duke University Press, Durham, NC) pp 3-23

Emmerson D K, 1984, “'Southeast Asia': what's in a name?” Journal of Southeast Asian Studies $151-21$

Ferguson J, 1990 The Anti-politics Machine: 'Development', Depolitization, and Bureaucratic Power in Lesotho (Cambridge University Press, Cambridge)

Gilmore D, 1990, "On Mediterranean studies" Current Anthropology 31395 - 396

Gregory D, 1994 Geographical Imaginations (Blackwell, Oxford)

Harley J B, 1992, "Deconstructing the map", in Writing Worlds: Discourse, Text and Metaphor in the Representation of Landscape Eds T J Barnes, J S Duncan (Routledge, London) pp 231 - 247

Harvey D, 1996 Justice, Nature and the Geography of Difference (Blackwell, Oxford)

Hill A M, 1998 Merchants and Migrants: Ethnicity and Trade Among Yunnanese Chinese in Southeast Asia (Yale University Southeast Asia Studies, New Haven, CT)

Hill L, Hitchcock M, 1996, "Anthropology”, in An Introduction to Southeast Asian Studies Eds M Halib, T Huxley (I B Tauris, London) pp $11-45$

Hirschman C, Keyes C F, Hutterer K (Eds), 1992 Southeast Asian Studies in the Balance: Reflections from America (The Association for Asian Studies, Ann Arbor, MI)

Howitt R, 1998, "Scale as relation: musical metaphors of geographical scale" Area 3049 - 58

Jonsson H, 1998, "Forest products and peoples: upland groups, Thai politics and regional space" Sojourn $131-37$

Jonsson H, 1999 Shifting Social Landscape: Mien (Yao) Upland Communities and Histories in State-client Settings (University Microfilms Incorporated, Ann Arbor, MI)

Kelly P F, 1997, "Globalization, power and the politics of scale in the Philippines" Geoforum 28 $151-171$

Keyes C F, 1992, "A conference at Wingspread and rethinking Southeast Asian studies", in Southeast Asian Studies in the Balance: Reflections from America Eds C Hischman, C F Keyes, K Hutterer (The Association for Asian Studies, Ann Arbor, MI) pp 2-4

Leach E, 1954 Political Systems of Highland Burma: A Study of Kachin Social Structure (London School of Economics and Political Science, London)

Leach E R, 1961, "The frontiers of 'Burma'" Comparative Studies in Society and History 3 49-68

Lehman F K, 1963 The Structure of Chin Society: A Tribal People of Burma Adapted to a NonWestern Civilization (University of Illinois Press, Champaign, IL)

Lefebvre H, 1976-78 De l'État [The state] 4 volumes (Union Générale d'Éditions, Paris)

Lefebvre H, 1991 The Production of Space (Blackwell, Oxford)

Lewis M W, Wigen K E, 1997 The Myth of Continents: A Critique of Metageography (University of California Press, Berkeley, CA)

McKinnon J, Michaud J, 2000, "Introduction: Montagnard domain in the South-East Asian massif", in Turbulent Times and Enduring Peoples: Mountain Minorities in the South-East Asian Massif Ed. J Michaud (Curzon, Richmond) pp 1-25

McVey R, 1978, "Introduction: local voices, central power", in Southeast Asian Transitions: Approaches through Social History Ed. R McVey (Yale University Press, New Haven, CT) $1-27$

Marston S A, 2000, "The social construction of scale" Progress in Human Geography 24 219-242

Martínez O J, 1994, "The dynamics of border interaction: new approaches to border analysis", in Global Boundaries: World Boundaries, Volume 1 Ed. C H Schofield (Routledge, London) pp $1-15$

Means G P, 2000, "Human sacrifice and slavery in the 'unadministered' areas of Upper Burma during the colonial era" Sojourn 15 184-221

Michaud J (Ed.), 2000 Turbulent Times and Enduring Peoples: Mountain Minorities in the SouthEast Asian Massif (Curzon, Richmond)

Palat R A, 1996, "Fragmented visions: excavating the future of area studies in a post-American world" Review $19269-315$ 
Pasuk Phongpaichit, Sungsidh Piriyarangsan, Nualnoi Treerat, 1998 Guns, Girls, Gambling, Ganja: Thailand's Illegal Economy and Public Policy (Silkworm Books, Chiangmai)

Pina-Cabral J, 1989, "The Mediterranean as a category of regional comparison: a critical view" Current Anthropology $30399-406$

Pluvier J M, 1974 South-East Asia from Colonialism to Independence (Oxford University Press, Kuala Lumpur)

Porter D J, 1995 Wheeling and Dealing: HIV and Development on the Shan State Borders of Myanmar (UNDP, New York)

Reid A, 1988 Southeast Asia in the Age of Commerce, 1450 - 1680, Volume 1, The Land Below the Winds (Yale University Press, New Haven, CT)

Reid A, 1993 Southeast Asia in the Age of Commerce, 1450-1680, Volume 2, Expansion and Crisis (Yale University Press, New Haven, CT)

Reynolds C J, 1995, "A new look at old Southeast Asia" Journal of Asian Studies 54419 - 446

Reynolds C J, McVey R, 1998 Southeast Asian Studies: Reorientations; The Frank H. Golay Memorial Lectures 2 and 3 (Cornell University Southeast Asia Program, Ithaca, NY)

Rigg J, Scott P, 1992, "The rise of the naga: the changing geography of South-East Asia, 1965-90", in The Changing Geography of Asia Eds G P Chapman, K M Baker (Routledge, London) pp $74-121$

Robb P, 1997, "The colonial state and constructions of Indian identity: an example on the northeast frontier in the 1880s" Modern Asian Studies 31 245-283

Scott J C, 1998 Seeing Like a State: How Certain Schemes to Improve the Human Condition Have Failed (Yale University Press, New Haven, CT)

Scott J C, 2000, "Hill and valley in Southeast Asia, or ... why civilizations can't climb hills", paper for the workshop "Beyond Borders: (Il)licit Flows of Objects, People and Ideas", Centre d'Études et Recherches Internationales, Paris, 1 - 4 July

Shapiro M, Schiffman H F, 1983 Language and Society in South Asia (Foris Publications, Dordrecht)

Small Arms Survey 2001: Profiling the Problem 2001 (Oxford University Press, Oxford)

Smith N, 1990 Uneven Development: Nature, Capital and the Production of Space 2nd edition (Blackwell, Oxford)

Smith N, 1992, "Contours of a spatialized politics: homeless vehicles and the production of geographical scale" Social Text 33 55-81

Smith N, 1995, "Remaking scale: competition and cooperation in prenational and postnational Europe", in Competitive European Peripheries Eds H Eskelinen, F Snickars (Springer, Berlin) pp $59-74$

Smith N, Dennis W, 1997, "The restructuring of geographical scale: coalescence and fragmentation of the Northern core region" Economic Geography 63160 - 182

Sobhan R, 1999 Transforming Eastern South Asia: Building Growth Zones for Economic Cooperation Centre for Policy Dialogue and the University Press Limited, Dhaka

Sobhan R, 2000 Rediscovering the Southern Silk Route: Integrating Asia's Transport Infrastructure (University Press, Dhaka)

Soja E, 1989 Postmodern Geographies: The Reassertion of Space in Critical Social Theory (Verso, London)

Solheim W G II, 1985, “، “Southeast Asia”: what's in a name', another point of view” Journal of Southeast Asian Studies 16141 - 147

Soucek S, 2000 A History of Inner Asia (Cambridge University Press, Cambridge)

Swyngedouw E, 1997, "Excluding the other: the production of scale and scaled politics", in Geographies of Economies Eds R Lee, J Wills (Arnold, London) 167-176

Tarling N, 1961 A Concise History of Southeast Asia (Praeger, New York)

Tarling N (Ed.), 1999 The Cambridge History of Southeast Asia 2nd edition (Cambridge University Press, Cambridge) (two volumes)

Tate D J M, 1971 The Making of Modern South-East Asia, Volume 1 (Oxford University Press, Kuala Lumpur

Tate D J M, 1979 The Making of Modern South-East Asia, Volume 2 (Oxford University Press, Kuala Lumpur)

van Schendel W, Mey W, Dewan A K, 2000 The Chittagong Hill Tracts: Living in a Borderland (White Lotus, Bangkok)

van Spengen W, 2000 Tibetan Border Worlds: A Geohistorical Analysis of Trade and Traders (Kegan Paul, London) 
Volkman T A, 1998, "Crossing borders: the case of area studies - in an increasingly interconnected world, the discipline of area studies is at a turning point" Ford Foundation Report 2928 -29

von Fürer-Haimendorf C, 1939 The Naked Nagas (Methuen, London)

von Fürer-Haimendorf C, 1964 The Sherpas of Nepal: Buddhist Highlanders (John Murray, London)

Vorasakdi Mahatdhanobol, 1998 Chinese Women in the Thai Sex Trade Ed. P Trichot (Institute of Asian Studies, Chulalongkorn University, Bangkok)

Walker A, 1999 The Legend of the Golden Boat: Regulation, Trade and Traders in the Borderlands of Laos, Thailand, Burma and China (Curzon Press, London)

Weighing the Balance: Southeast Asian Studies Ten Years After-Held in New York City, November 15 and December 10, 1999, 2000. Proceedings of Two Meetings (Social Science Research Council, New York)

Wheeler J H, Kostbade J T, 1993 Essentials of World Regional Geography (Harcourt Brace Jovanovich, Fort Worth, TX)

Wijeyewardene G, 1990 Ethnic Groups Across National Boundaries in Mainland Southeast Asia (Institute of Southeast Asian Studies, Singapore)

Wijeyewardene G, 1993, "Southeast Asian borders: report of a seminar held at the Australian National University, 28 - 30, October 1993" Thai - Yunnan Project Newsletter 23 (December)

Williams L E, 1976 Southeast Asia: A History (Oxford University Press, New York)

Wolf E R, 1982 Europe and the People Without History (University of California Press, Berkeley, CA)

Wolters O W, 1999 History, Culture, and Region in Southeast Asian revised edition Cornell University Southeast Asia Program Publications, in cooperation with the Institute of Southeast Asian Studies, Singapore, Ithaca, NY

Wyatt D K, 1997, "Southeast Asia 'inside out', 1300 - 1800: a perspective from the interior" Modern Asian Studies 31689 - 709 